\title{
Emanuel Halicz - sylwetka nie tylko naukowa
}

Zarys treści: Sylwetka naukowa i polityczna Emanuela Halicza, historyka XIX w., współpracownika emigracyjnych „Zeszytów Historycznych”.

Outline of content: The article presents a scientific and political profile of Emanuel Halicz, a historian of the $19^{\text {th }}$ century, and collaborator of the émigré periodical Zeszyty Historyczne.

Słowa kluczowe: polscy historycy, polscy Żydzi, oficerowie polityczni Wojska Polskiego, Instytut Kształcenia Kadr Naukowych, Wojskowa Akademia Polityczna, emigranci marcowi, Zeszyty Historyczne, powstanie styczniowe 1863

Keywords: Polish historians, Polish Jews, March 1968, political officers of the Polish Army, Institute for Training Scientific Cadres, Military Political Academy, March emigrants, Zeszyty Historyczne, January Uprising 1863

Po 1968 r. wyjechało z Polski wielu historyków. Należy tu wymienić chociażby takie osoby jak: Lucjan Dobroszycki (1925-1995), Bolesław Drukier (1913-2006), Dawid Fajnhauz (1920-2004), Łukasz Hirszowicz (1920-1993), Henryk Katz (19141998), Paweł Korzec (1919-2012), Karol Lapter (1912-2003), Józef Lewandowski (1923-2007) czy Aleksander Litwin (1909-1984). W PRL oczywiście byli skazani na zapomnienie. Ich sytuacja, w odróżnieniu od tych kolegów, którzy zdecydowali się nie wracać do Polski w 1945, była zupełnie inna. Nie wszyscy odnaleźli się $\mathrm{w}$ trudnych warunkach emigracyjnych. Z racji swojego wcześniejszego zaangażowania w komunizm, nie byli mile widziani przez „starą niezłomną emigrację". Ostatnio odszedł jeden z ostatnich z tej grupy, wybitny badacz XIX stulecia - Emanuel Halicz (1921-2015).

Historyk urodził się 19 września 1921 r. we Lwowie jako Emanuel Halpern, syn Leona i Róży. Pochodził z rodziny polskich Żydów ${ }^{1}$. Od 1939 r. studiował

${ }^{1}$ Podstawowe informacje: Kto jest kim w Polsce, red. B. Cynkier, wyd. 4, Warszawa 2001, s. 292;

T. Rutkowski, Nauki historyczne w Polsce 1944-1970. Zagadnienia polityczne i organizacyjne, 
na Wydziale Historycznym na ukraińskim uniwersytecie we Lwowie. Od 1940 r. był członkiem Komsomołu. W czerwcu 1941 r. został ewakuowany do Maryjskiej Autonomicznej Socjalistycznej Republiki Radzieckiej. Tam pracował jako nauczyciel.

Od października 1943 r. rozpoczął służbę w armii Zygmunta Berlinga jako oficer polityczny. Lata 1943-1945 spędził na bojowym szlaku od Oki po Łużyce. Wśród jego kolegów był m.in. Wojciech Jaruzelski. Działania wojenne ukończył w stopniu kapitana jako żołnierz 9. Drezdeńskiej Dywizji Piechoty (Halpern Emanuel, syn Leona). Co ciekawe, w tej samej jednostce służyła osoba zapisana w dokumentach jako porucznik Emanuel Halicz. Emanuel Halpern zmienił nazwisko na Halicz w 1947 r.

Po zakończeniu działań wojennych pozostał w armii. W latach 1947-1950 w stopniu podpułkownika był szefem Wydziału Propagandy Zarządu Politycznego Okręgu Wojskowego Kraków. Od kwietnia 1945 r., co normalne w przypadku oficerów politycznych, był członkiem PPR, następnie PZPR. W 1947 r. nostryfikował dyplom ukończenia studiów na Uniwersytecie Jagiellońskim. Tam w 1950 r. obronił pracę doktorską „Sprawa chłopska w powstaniu styczniowym” pod kierunkiem Henryka Mościckiego (1881-1952).

W październiku 1950 r. Główny Zarząd Polityczny Wojska Polskiego skierował go na studia do Instytutu Kształcenia Kadr Naukowych (IKKN). Była to wyższa szkoła partyjna powołana w 1950 r. przy Komitecie Centralnym PZPR. Jej zadaniem było kształcenie kierowniczych kadr naukowych w oparciu o wzorce nauki radzieckiej (Akademia Nauk społecznych przy KC WKP (b)). W ramach instytucji (łącznie siedem katedr) istniał Wydział Historii Polski, Historii Powszechnej i Historii WKP(b), kierowany przez osławioną Żannę Kormanową. W jego ramach powołano: Katedrę Historii Polski (kierownik: Stanisław Arnold, zastępcy: Żanna Kormanowa, Tadeusz Daniszewski), Katedrę Historii WKP(b) (kierownik: Józef Kowalski, zastępca: Weronika Gostyńska) i Katedrę Historii Powszechnej (kierownik: Bronisław Krauze $)^{2}$. Poza Arnoldem, który miał dość pokaźny dorobek historyczny, wymienieni badacze byli po pierwsze działaczami partii, dopiero na drugim miejscu historykami. Nie przekreśla to oczywiście ich dorobku, w większości byli to historycy ruchu robotniczego. Pod ich kierunkiem w placówce zaczęły powstawać doktoraty - dla przykładu Mieczysław Rakowski był uczniem Bronisława Krauzego. Aspiranci tej szkoły (obowiązywało nazewnictwo i wzory radzieckie) wywodzili się ze szkół i instancji partyjnych, instytucji państwowych, wojska,

Warszawa 2007; http://kulturaparyska.com/pl/ludzie/pokaz/e/emanuel_halicz?q=emanuel\%20 halicz (dostęp: 20.06.2016). Materiały archiwalne dotyczące Emanuela Halicza znajdują się min. w Archiwum Akt Nowych - Akademia Nauk Społecznych, wyk 42/56 oraz w Centralnym Archiwum Wojskowym.

2 B. Bińko, Instytut Kształcenia Kadr Naukowych przy KC PZPR - narzędzie ofensywy ideologicznej w nauce i szkolnictwie wyższym, „Kultura i Społeczeństwo” 40 (1996), nr 2, s. 199-214; T. Rutkowski, op. cit., s. 319; J. Szumski, Polityka a historia. ZSRR wobec nauki historycznej w Polsce w latach 1945-1964, Warszawa 2016, s. 189-193. 
resortu bezpieczeństwa oraz $\mathrm{z}$ asystentury na wyższych uczelniach. Pierwszy rocznik liczył 78 osób. Główny Zarząd Polityczny WP razem z ppłk. Emanuelem Haliczem skierował rozkazem do szkoły także ppłk. Bronisława Baczko, mjr. Kazimierza Ochockiego i kpt. Zbigniewa Gaczyka.

W 1954 r. IKKN został przekształcony w Instytut Nauk Społecznych (INS) przy KC PZPR. Pomimo ideologicznego statusu tej instytucji i krótkiego okresu działania (do 1957 r.) przewinęło się przez nią wielu przyszłych wybitnych historyków. Kolegami Halicza z roku byli: badacz dziejów starożytnych Roman Kamienik, mediewista Stanisław Piekarczyk, sinolog Wacław Rodziński czy historyk idei Bronisław Baczko ${ }^{3}$.

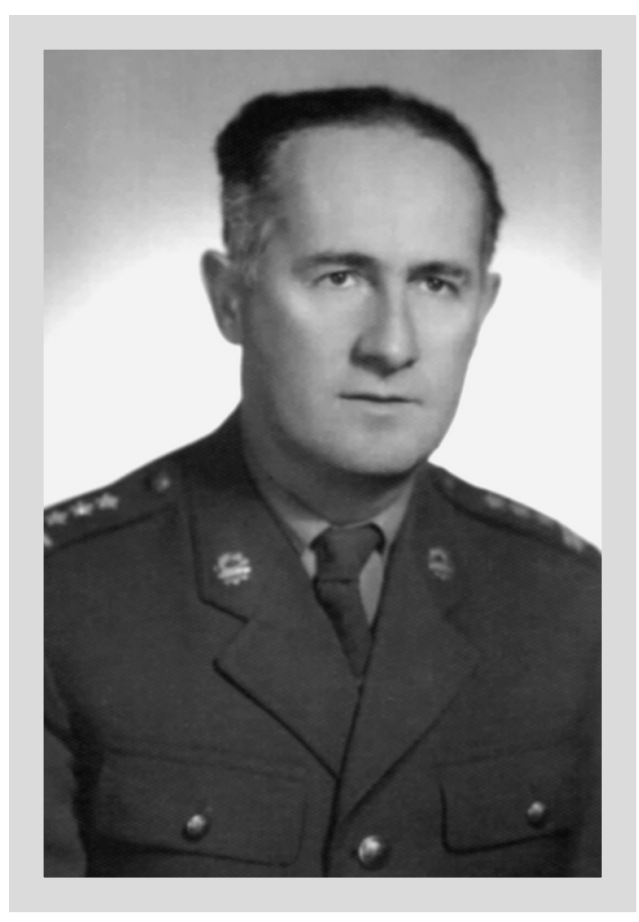
W kolejnych latach przez szkołę prze-

winęli się też: Jan Borkowski, Marian M. Drozdowski, Karol Grünberg, Jerzy Holzer, Jan Kancewicz, Ryszard Kołodziejczyk, Marian Malinowski, Jan Molenda, Walentyna Najdus, Ryszard Nazarewicz, Henryk Słabek, Jerzy Tomaszewski, Maria Turlejska, Feliks Tych, Janusz Żarnowski, Marian Żychowski.

Od 1952 r. Emanuel Halicz był pracownikiem IKKN/INS, zatrudnionym na pół etatu. W 1954 uzyskał tam stopień kandydata nauk historycznych (ówczesna habilitacja; tytuł: „Kwestia chłopska w Królestwie Polskim na przełomie lat 50-60-tych XIX wieku"). W tym samym roku został docentem. W INS pod jego kierunkiem pracę doktorską pt. „Polityka czartoryszczyzny w okresie powstania 1863-1864” obroniła w 1956 r. Irena Koberdowa (1916-2008). Jej postać zapisała się w polskiej historiografii przede wszystkim badaniami dotyczącymi drugiej połowy XIX w., a zwłaszcza ruchu robotniczego. W odróżnieniu od dużej grupy historyków ruchu robotniczego pracujących w Zakładzie Historii Partii przy KC PZPR, Wyższej Szkole Nauk Społecznych (WSNS) czy Centralnym Archiwum PZPR, była ona minimalnie zaangażowana $\mathrm{w}$ działalność partyjną.

Praca Halicza w tej instytucji szkolnictwa partyjnego trwała jedynie do $1956 \mathrm{r}$. Instytut Nauk Społecznych przy KC PZPR na przełomie 1956 i 1957 r. został zresztą

\footnotetext{
${ }^{3}$ B. Bińko, Skąd przychodzili, dokąd zmierzali... aspiranci pierwszego rocznika Instytutu Kształcenia Kadr Naukowych przy KC PZPR, w: Komunizm. Ideologia, system, ludzie, red. T. Szarota, Warszawa 2001, s. 192-204.
} 
rozwiązany, a w jego miejsce utworzono Wyższą Szkołę Nauk Społecznych przy KC PZPR (1957). Tam też trafiła większość pracowników naukowych.

Poza pracą na tej uczelni, której monografii do tej pory niestety brak, historyk pracował jednocześnie na Uniwersytecie Warszawskim w latach 1952-1954 i 19601962. Jako wojskowy w 1951 r. Halicz został członkiem Komisji Historyczno-Wojskowej Ministerstwa Obrony Narodowej. Zajmował się tam historią wojskowości XVIII-XIX w. W tym okresie ukazały się jego pierwsze publikacje ${ }^{4}$. Jednocześnie w latach 1954-1956 był członkiem komitetu redakcyjnego nieukazującego się już czasopisma „Studia i Materiały do Historii Wojskowości”.

Trzeba jednak podkreślić, że Emanuel Halicz ze względu na wiek nie odegrał jakiejś istotnej roli w stalinizacji nauki historycznej w Polsce. Będąc młodym pracownikiem naukowym instytucji partyjnych, mógł jedynie sekundować starszym kolegom historykom. Warto jednak zwrócić uwagę, że był uczestnikiem słynnej konferencji otwockiej (28.12.1951-12.01.1952).

Pułkownik, pozostający do dyspozycji wojska, w 1957 r. mógł został skierowany do pracy w Wojskowym Instytucie Historycznym. Stało się jednak inaczej. Kolejnym miejscem pracy stała się Wojskowa Akademia Polityczna (WAP) w Warszawie. Uczelnia istniała od 1951 r., pierwotnie jako Akademia Wojskowo-Polityczna. W czerwcu 1957 minister obrony narodowej zmienił jej nazwę na Wojskową Akademię Polityczną. Jej patronem był Feliks Dzierżyński. Jeżeli IKKN był wzorowany na Instytucie Czerwonej Profesury, to WAP był kopią Akademii im. W. Lenina w Moskwie. Kadra uczelni początkowo rekrutowała się wyłącznie z oficerów politycznych WP. W grudniu 1958 r. utworzono fakultet historyczny (później wydział). Szkoła kształciła słuchaczy początkowo na poziomie studiów magisterskich.

Halicz w chwili zatrudnienia w WAP był jednym z kilku wojskowych pracowników posiadających tytuł doktora ${ }^{6}$. Miejscem pracy był Wydział Historyczno-Polityczny. Dziekanem w latach 1957-1968 był zasłużony historyk dziejów nowożytnych - Janusz Woliński. Emanuel Halicz w okresie 1958-1968 był kierownikiem

\footnotetext{
${ }^{4}$ Polska sztuka wojenna $w$ okresie powstania styczniowego, Warszawa 1954; Kwestia chłopska $w$ Królestwie Polskim w dobie powstania styczniowego, Warszawa 1955; Rola nurtu plebejskiego w polskich walkach narodowo-wyzwoleńczych w latach 1794-1864, oprac. E. Halicz, M. Żychowski, Warszawa 1955; Rola nurtu plebejskiego w polskich powstaniach narodowych XVIII i XIX wieku, oprac. E. Halicz, przy udziale M. Żychowskiego, Z. Mańkowskiego i W. Jakóbczyka, Warszawa 1956; Optymizm czy pesymizm? Chłopstwo w walkach narodowowyzwoleńczych, „Kwartalnik Historyczny" 64 (1957), z. 4/5, s. 136-141.

5 Wykaz członków Komitetu Redakcyjnego i Redakcji „Studiów i Materiałów do Historii Wojskowości” w latach 1954-1987, „Studia i Materiały do Historii Wojskowości” 30 (1988), s. 40; T.M. Nowak, Z dziejów organizacji badań nad historia wojskowa w Polsce Ludowej, „Studia i Materiały do Historii Wojskowości” 30 (1988), s. 19-42.

6 A. Ciupiński, Wojskowa Akademia Polityczna im. F. Dzierżyńskiego 1951-1986, Warszawa 1986, s. 61; D.S. Kozerawski, Wyższe szkolnictwo wojskowe w Polsce w latach 1947-1967, Warszawa 2005, s. 295, przyp. 18.
} 
Katedry Historii Polski ${ }^{7}$ Z $\mathrm{Z}$ jego katedrą byli związani też: Tadeusz Jędruszczak, Józef Lewandowski, Władysław Tomkiewicz i Maria Turlejska. Wobec braku kadry wojskowej, WAP zatrudnił cywilnych historyków, na co dzień pracujących na Uniwersytecie Warszawskim. Należy tu wymienić takie nazwiska jak: Stanisław Arnold, Ludwik Bazylow, Juliusz Bardach, Tadeusz Cieślak, Jerzy Dowiat, Stanisław Herbst, Karol Lapter, Marian Leczyk czy Andrzej Zahorski. W odróżnieniu od innych placówek nauki partyjnej (Wyższa Szkoła Nauk Społecznych), gdzie także pracowali historycy - tu wykładali wybitni naukowcy. Efektem szeroko zakrojonych badań były wartościowe publikacje. Była to oczywiście zasługa zatrudnionych pracowników naukowych spoza wojska. W momencie, gdy Główny Zarząd Polityczny WP objął gen. Jaruzelski (1965), rozpoczął się proces usuwania cywilnych pracowników z Akademii. Ostatecznie w roku 1968 nastąpiła wymiana większości kadry. Miejsce liczących się historyków z pokaźnym dorobkiem zajęli wojskowi, często niemający stopni naukowych. Co ciekawe, w połowie lat siedemdziesiątych WAP uzyskała prawo do nadawania stopni naukowych doktora i doktora habilitowanego ${ }^{8}$.

Główne zainteresowania badawcze Halicza w tym czasie skupiały się na historii Polski i historii powszechnej XIX w. Historyk badał dzieje polskich powstań narodowych, opublikował wiele opracowań na ten temat. Można bez przesady określić go historykiem powstania styczniowego. Wraz z innymi uczonymi wchodził w skład komisji obchodów setnej rocznicy jego wybuchu. Jako ekspert w tej dziedzinie był konsultantem filmu dokumentalnego Powstanie styczniowe z $1962 \mathrm{r}$. Z kolei w latach 1956-1970 był członkiem komisji do wydania źródeł z tego okresu przy Polskiej Akademii Nauk i Akademii Nauk ZSRR ${ }^{9}$. Był też redaktorem wydawnictwa źródeł Naczelnej Dyrekcji Archiwów Państwowych pt. Proces Romualda Traugutta i członków Rządu Narodowego ${ }^{10}$. Duże zasługi miał jako wydawca licznych tekstów źródłowych $\mathrm{z}$ okresu powstania styczniowego ${ }^{11}$. Istotne znaczenie mają zwłaszcza

7 E. Horoszko, P. Kaczmarska, Wojskowa Akademia Polityczna im. Feliksa Dzierżyńskiego 19511990 w świetle akt Archiwum Ministerstwa Obrony Narodowej, „Rocznik Archiwalno-Historyczny Centralnego Archiwum Wojskowego” (2011), nr 4, s. 167-206; „Zeszyty Naukowe WAP im. F. Dzierżyńskiego" (1981), nr 107 (O historii i historykach w Wojskowej Akademii Politycznej).

8 Szerzej o koncepcjach Jaruzelskiego na funkcjonowanie WAP zob. L. Kowalski, Generał ze skaza. Biografia wojskowa gen. armii Wojciecha Jaruzelskiego, Warszawa 2001, s. 225-228. W tej publikacji E. Halicz występuje w indeksie z imieniem Eugeniusz!

9 Powstanie Styczniowe. Materialy i dokumenty, t. 1: Dokumenty Komitetu Centralnego Narodowego i Rządu Narodowego 1862-1864, red. E. Halicz, S. Kieniewicz, I. Miller, Wrocław 1968. W 1970 r. po usunięciu Halicza z Komisji zastąpiła go Wiktoria Śliwowska.

10 Proces Romualda Traugutta i członków Rządu Narodowego. Akta Audytoriatu Polowego z lat 1863/1864, t. 1-4, red. E. Halicz, Warszawa 1960-1961.

${ }^{11}$ Instrukcja powstańcza Ludwika Mierosławskiego, przyg. do dr. E. Halicz, wstęp E. Halicz, Warszawa 1958; Demokracja polska w powstaniu styczniowym. Wybór źródeł, red. E. Halicz, Wrocław 1961; Nurty lewicowe $w$ dobie polskich powstań narodowych 1794-1849. Wybór źródel, red. E. Halicz, wstęp H. Jabłoński, Wrocław 1961. 
edycje pamiętników ${ }^{12}$. Temat insurekcyjny i sprawa polska w XIX w. powracał $\mathrm{w}$ wielu jego publikacjach ${ }^{13}$.

Swoje zainteresowania kierował też ku początkom XIX w. Ważna i do tej pory w pewnej mierze aktualna jest praca Geneza Księstwa Warszawskiego (Warszawa 1962). Szczególnym wydarzeniem była edycja broszury sekretarza Tadeusza Kościuszki, Józefa Pawlikowskiego, Czy Polacy wybić się mogq na niepodległość? Halicz dołączył też do toczącej się od śmierci naczelnika dyskusji historyków na jego temat ${ }^{14}$. Brał czynny udział w debacie na temat ekranizacji Popiołów Stefana Żeromskiego w reżyserii Andrzeja Wajdy (1965).

W odróżnieniu od części tzw. historyków partyjnych czy wojskowych kolegów z WAP, Emanuel Halicz publikował solidne źródłowo prace, a nie propagandowe broszury ${ }^{15}$. Jego kariera jako historyka rozwijała się szybko. W $1960 \mathrm{r}$. Halicz został profesorem nadzwyczajnym (jako pierwszy wojskowy w dziejach

12 F. Kopernicki, Pamiętnik $z$ powstania styczniowego. Notatki $z$ powstania $w$ województwie kaliskim 1863 i 1864 r., wstęp i przypisy E. Halicz, przygot. do druku E. Halicz, L. Ratajczyk, Warszawa 1959; F.L. von Erlach, Partyzantka $w$ Polsce $w$ roku 1863. Na podstawie własnych obserwacji zbieranych na teatrze walki od marca do sierpnia, przygot. do druku E. Halicz, Warszawa 1960; W.I. Nowacki-Kopaczyński, Pamiętnik Junoszy, oficera polskich żandarmów w powstaniu styczniowym, przygot. do druku E. Halicz, L. Ratajczyk, Warszawa 1960; J. Oxiński, Wspomnienia z powstania polskiego 1863-1864, oprac., wstęp i przypisy E. Halicz, Warszawa 1965.

${ }^{13}$ La question polonaise a Tilsitt, „Acta Poloniae Historica” (1962), s. 45-65; Sprawozdanie generała Edmunda Rózyckiego z misji na Wschodzie w 1863/64 roku, „Zeszyty Naukowe WAP. Seria Historyczna” (1962), z. 7, s. 59-68; Koncepcje militarne powstania styczniowego i ich realizacja, „Studia i Materiały do dziejów Wielkopolski i Pomorza” 8 (1963), z. 2, s. 6-22; Korespondencja T. Berga $z$ Aleksandrem II $w$ związku $z$ procesami politycznymi $w$ Królestwie Polskim $w$ latach powstania styczniowego, „Zeszyty Naukowe WAP. Seria historyczna” (1963), z. 9 (31), s. 105-112; Marks o sprawie polskiej, „Kwartalnik Historyczny” 70 (1963), z. 1, s. 116-120; Od Wegrowa do Opatowa, „Zeszyty Naukowe WAP. Seria historyczna” (1963), z. 29, s. 136-141; U źródeł dyktatury Romualda Traugutta, w: $Z$ dziejów wojny i polityki. Księga pamiątkowa ku uczczeniu siedemdziesiątej rocznicy urodzin prof. dr Janusza Wolińskiego, Warszawa 1964, s. 54-61; W sprawie Nikiforowa, „Zeszyty Naukowye WAP. Seria historyczna” (1965), z. 12 (40), s. 76-80; Katechizm demokratyczny polskich walk narodowowyzwoleńczych w XIX wieku, „Zeszyty Naukowe WAP. Seria Historyczna” (1966), z. 14, s. 37-53; Rys ogólny działań władz rządowych w Królestwie Polskim za rok 1863, w: Studia Historyczne Stanisławowi Herbstowi na sześćdziesięciolecie urodzin w upominku uczniowie, koledzy, przyjaciele, red. J. Woliński, Warszawa 1967, s. 117-123; Sprawa polska w świetle nassauskiego memoriału Steina, w: Wiek XIX. Prace ofiarowane Stefanowi Kieniewiczowi $w 60$ rocznice urodzin, red. B. Grochulska, B. Leśnodorski, A. Zahorski, Warszawa 1967, s. $126-132$.

14 J. Pawlikowski, Czy Polacy wybić się moga na niepodległość, do druku przygot. i wstępem opatrzył E. Halicz, Warszawa 1967; Tadeusz Kościuszko a pierwsza wojna polska (1806-1807), „Zeszyty Naukowe Wojskowej Akademii Politycznej" (1960), z. 2; Kościuszko i koleje historyczne tradycji kościuszkowskiej, „Zeszyty Naukowe WAP. Seria historyczna” (1968), z. 18 (54).

15 Wyjątek może stanowi publikacja: Ksztattowanie się ludowego charakteru Wojska Polskiego w latach drugiej wojny światowej, w: $Z$ dziejów ludowego Wojska Polskiego, red. I. Pawłowski, Warszawa 1965, s. 26-41. 
WAP). Był też członkiem nowo powstałego Komitetu Nauk Historycznych PAN (1959-1966), członkiem komitetu wydawniczego Instytutu Historii PAN i Instytutu Słowianoznawstwa Akademii Nauk ZSRR, Komitetu Naukowego Obchodu Tysiąclecia Państwa Polskiego (1965-1966), Rady Głównej Szkolnictwa Wyższego (1963-1966) i Rady Wyższego Szkolnictwa Wojskowego (1963-1966). W 1965 r. był członkiem kilkunastoosobowej delegacji polskiej na XII Międzynarodowy Kongres Nauk Historycznych w Wiedniu. Jako uznany badacz był recenzentem prac doktorskich powstałych na seminarium Stefana Kieniewicza w Instytucie Historycznym UW ${ }^{16}$. Sam Kieniewicz niewątpliwie cenił prace Halicza, o czym świadczą jego późniejsze recenzje ${ }^{17}$.

Będąc członkiem PZPR, dawnym pułkownikiem WP, cywilnym historykiem zajmującym się dziejami powstania styczniowego, profesorem WAP, zapewne nie spodziewał się nagłego załamania swojej kariery w Polsce Ludowej. Rok 1968 był $\mathrm{w}$ istocie dla niego i wielu innych katastrofą. Został usunięty z Wojskowej Akademii Politycznej. Utrata pracy, a także nieprzychylny klimat spowodowały, że nie widząc dla siebie perspektyw w PRL - postanowił wyemigrować. W $1971 \mathrm{r}$. wyjechał z rodziną do Danii. W tym kraju znalazł się też jego kolega Bolesław Drukier (w latach 1953-1957 prorektor INS, 1957-1968 prorektor WSNS), który wykładał na uniwersytecie w Roskilde. W pobliskiej Szwecji zatrudnienie znaleźli koledzy z WAP - Józef Lewandowski i Karol Lapter. Halicz już w 1972 r. został zdegradowany przez ministra obrony narodowej Wojciecha Jaruzelskiego do stopnia szeregowca. Stał się też obiektem zainteresowania służb specjalnych PRL ${ }^{18}$.

W latach 1972-1982 był profesorem uniwersytetu w Odense, a następnie w latach 1982-1990 uniwersytetu w Kopenhadze. Pozostawał aktywny zawodowo. W 1982 r. ukazała się jego ważna książka Polish national liberation struggle and the genesis of the modern nation ${ }^{19}$. $\mathrm{Z}$ okresu duńskiego pochodzi też kilka innych ważnych publikacji ${ }^{20}$. Wśród nich wyróżnia się praca Russia and Denmark 1856-

16 A. Grzybowski, Organizacja Miejska $w$ Warszawie w okresie Powstania Styczniowego (1963); S. Król, X Pawilon Cytadeli Warszawskiej - główne więzienie polityczne Królestwa Polskiego w latach 1833-1856 (1965); F. Ramotowska, Rzad carski wobec ruchu narodowego w Królestwie Polskim w okresie manifestacji 1861-1862 (1966).

17 Odmiennego zdania był Henryk Wereszycki, zob. S. Kieniewicz, H. Wereszycki, Korespondencja $z$ lat 1947-1990, wstęp i oprac. E. Orman, Kraków 2013, s. 679 (list Wereszyckiego do Kieniewicza z 30.09.1984).

18 Instytut Pamięci Narodowej, Ka 0024/28, t. 1-5.

19 Polish national liberation struggles and the genesis of the modern nation. Collected papers, transl. R.A. Clarke, Odense 1982. Recenzja: H.H. Hennings, „Jahrbücher für Geschichte Osteuropas” 32 (1984), z. 4, s. 598-599.

20 Partisan warfare in 19th century Poland: the development of a concept, transl. J. Fraser, Odense 1975; Russian policy towards the Scandinavian countries in 1856-1864, Washington 1985; The 1863 Polish Uprising and Scandinavia. The Year 1863, the Turning-Point in Russo-Scandinavian Relations, København 1988; Poland's memorandum to the Peace Congress in Rome, November 
$1864^{21}$. Dzieło Halicza to owoc imponującej erudycji. Na gruncie międzynarodowym przyczyniło się do pogłębienia znajomości dziejów dyplomacji europejskiej omawianego ośmiolecia.

$\mathrm{Na}$ emigracji Halicz współpracował z paryskimi „Zeszytami Historycznymi”, publikując na ich łamach kilka artykułów ${ }^{22}$ oraz recenzje ${ }^{23}$. Był też współpracownikiem pism „Historisk Tidskrift”24, „Zeitschrift für Ostmitteleuropa-Forschung”,

1891, ed. by E. Halicz, Copenhagen 1993; Aleksander Hercen i sprawa polska w latach posewastopolskiej wiosny (1856-1861), w: En slavist i humanismens tegn. Festskrift til Kristine Heltberg, København 1994, s. 117-127.

${ }^{21}$ Russia and Denmark 1856-1864.: A chapter of Russian policy towards the Scandinavian Countries, transl. R.A. Clarke, Copenhagen 1990. Recenzja: S. Kieniewicz, „Przegląd Historyczny” 82 (1991), z. 2, s. 337-340.

${ }^{22}$ Ksiądz Brzóska. Hierarchia kościelna a powstanie styczniowe, „Zeszyty Historyczne” (1980), z. 54, s. 40-58; "Le Nord” o konflikcie rosyjsko-polskim i o jego perspektywach, „Zeszyty Historyczne” (1985), z. 74, s. 58-66; Kraje skandynawskie wobec powstania styczniowego, „Zeszyty Historyczne” (1987), z. 81, s. 21-33; Aleksander II - Michaił Gorbaczow, „Zeszyty Historyczne” (1988), z. 85, s. $40-43$.

${ }^{23}$ N. Davies, God's Playground. A history of Poland, t. 1-2, New York 1982 - „Zeszyty Historyczne" (1982), z. 60, s. 210-216; Sprostowanie dot. notatki L. Muzyczki i K. Pluty-Czachowskiego (Zeszyty Historyczne nr 60) - „Zeszyty Historyczne” (1982), z. 60, s. 236; S. Kieniewicz, Historyk a świadomość narodowa, Warszawa 1982 - „Zeszyty Historyczne” (1984), z. 68, s. 201-207; K. Kersten, Narodziny systemu władzy. Polska 1943-1948, Paris 1986 - „Zeszyty Historyczne” (1986), z. 77, s. 143-147; Polska XIX wieku. Państwo, społeczeństwo, kultura, red. S. Kieniewicz, wyd. 3, Warszawa 1986 - „Zeszyty Historyczne” (1988), z. 84, s. 193-201; M. Król, Konserwatyści a niepodległość. Studia nad polska myśla konserwatywna XIX wieku, Warszawa 1985 - „Zeszyty Historyczne” (1989), z. 87, s. 204-207; A. Tuszyńska, Rosjanie w Warszawie, Paryż 1990 - „Zeszyty Historyczne” (1991), z. 96, s. 222-225; M. Waldenberg, Kwestie narodowe w Europie Środkowo-Wschodniej. Dzieje, idee, Warszawa 1992 - „Zeszyty Historyczne” (1994), z. 108, s. 209-213; T. Pióro, Armia ze skaza. W Wojsku Polskim 1945-1968. (Wspomnienia i refleksje), Warszawa 1994 - „Zeszyty Historyczne” (1995), z. 111, s. 196-201; H. Batowski, Zachód wobec granic Polski 1920-1949. Niektóre fakty mniej znane, Łódź 1995 - „Zeszyty Historyczne” (1996), z. 116, s. 162-165; A. Gill, Eine tragische Staatsgrenze. Geschichte der deutsch-polnischen Grenze von 1918-1945, Frankfurt am Main 1997 - „Zeszyty Historyczne” (1997), z. 121, s. 159-162; J. Tazbir, Polska na zakrętach dziejów, Warszawa 1997 - „Zeszyty Historyczne” (1998), z. 126, s. 190-196; A. Gill, Freiheitskëmpfe der Polen im 19. Jahrhundert. Erhebungen - Aufstande - Revolutionen, Frankfurt am Main 1997 - „Zeszyty Historyczne” (1998), z. 124, s. 195-199; M. Zybura, Niemcy w Polsce, Wrocław 2001 - „Zeszyty Historyczne” (2003), z. 143, s. 187-190; N. Davies, Powstanie '44, Kraków 2004 - „Zeszyty Historyczne” (2004), z. 149, s. 118-120; D. Beauvois, Trójkąt ukraiński. Szlachta, carat i lud na Wołyniu, Podolu i Kijowszczyźnie 1793-1914, Lublin 2005 - „Zeszyty Historyczne” (2005), z. 154, s. 195-199.

${ }^{24}$ H.H. Henning, Aussenpolitik in der Emigration. Die Exildiplomatie Adam Jerzy Czartoryskis 1830-1840, München 1978 - „Historisk Tidsskrift” 80 (1980), z. 1, s. 259-260; H. Werner Rautenberg, Der polnische Aufstand von 1863 und die europäische Politik im Spiegel der deutschen Diplomatie und der öffentlichen Meinung, Wiesbaden 1979 - „Historisk Tidsskrift” 81 (1981), z. 1, s. 318-319; N. Davies, God's Playground. A history of Poland, t. 1-2, New York 1982 "Historisk Tidsskrift” 82 (1982), z. 2, s. 177-179; A. Gill, Eine tragische Staatsgrenze. Geschichte der deutsch-polnischen Grenze von 1918-1945, Frankfurt am Main 1997 - „Historisk Tidsskrift” 98 (1998), z. 1, s. 225-228. 
gdzie opublikował' jeden artykuł25 i liczne recenzje ${ }^{26}$ oraz „Zeitschrift für Ostforschung" 27 .

W 1989 r. został zaproszony przez Polską Akademię Nauk, Uniwersytet Jagielloński i Towarzystwo Polonia na III Kongres Uczonych Polskiego Pochodzenia - odmówił jednak przyjazdu. Po zmianach w Polsce nawiązał współpracę z „Przeglądem Historycznym" ${ }^{28}$. W 1994 r. przywrócono mu utracony stopień wojskowy. Był odznaczony: Orderem Krzyża Grunwaldu (1945), Krzyżem Kawalerskim Orderu Odrodzenia Polski (1946), Medalem za Odrę, Nysę, Bałtyk (1956), Odznaką Tysiąclecia Państwa Polskiego (1966).

Odszedł historyk rzetelny i entuzjastyczne zaangażowany w badania historyczne, zabierając bezpowrotnie swe niewypowiedziane myśli, sugestie, propozycje rozwiązań, które mogłyby wzbogacić nasze postrzeganie przeszłości.

${ }^{25}$ Die Rolle des gebildeten Offiziers im Europa des 18. Jahrhunderts. Die Polnische Ritterakademie in den Jahren 1765-1794, „Zeitschrift für Ostmitteleuropa-Forschung” 38 (1989), z. 1, s. 82-94.

${ }^{26}$ Przemiany społeczne w Królestwie Polskim 1815-1864, red. W. Kula i J. Leskiewiczowa, Wrocław 1979 - „Zeitschrift für Ostmitteleuropa-Forschung” 30 (1981), z. 3, s. 437-439; F. Ramotowska, Rząd Narodowy Polski w latach 1863-1864. (Skład, organizacja, kancelaria), Łódź 1978 - „Zeitschrift für Ostmitteleuropa-Forschung” 30 (1981), z. 3, s. 441-444; Galicja w powstaniu styczniowym. Galicija v vosstanii 1863 goda, red. S. Kieniewicz, I. Miller, Wrocław 1980 - „Zeitschrift für Ostmitteleuropa-Forschung" 32 (1983), z. 3, s. 443-445; N. Davies, Heart of Europe. A Short Story of Poland, Oxford 1984 - „Zeitschrift für Ostmitteleuropa-Forschung” 37 (1988), z. 1, s. 143-147; Zarys powstania styczniowego opracowany w Warszawskiej Cytadeli, red. S. Kieniewicz, T. Kopriejewa, L. Szyłow, Wrocław 1986 - „Zeitschrift für Ostmitteleuropa-Forschung” 37 (1988), z. 2, s. 287-292; M. Tymowski, J. Kieniewicz, J. Holzer, Historia Polski, Paris 1986 - „Zeitschrift für Ostmitteleuropa-Forschung” 38 (1989), z. 1, s. 115-118; M. Tyrowicz, Jan Tyssowski i rewolucja 1846 r. w Krakowie. Dzieje porywu i pokuty, Kraków 1986 - „Zeitschrift für Ostmitteleuropa-Forschung" 38 (1989), z. 3, s. 460-461; Powstanie kościuszkowskie w dokumencie archiwalnym. Wolność, całość i niepodległość 1794, oprac. B. Sobolowa, Warszawa 1985 - „Zeitschrift für Ostmitteleuropa-Forschung” 40 (1991), z. 1, s. 134-136; H. Florkowska-Frančić, Emigracyjna działalność Agatona Gillera po powstaniu styczniowym, Wrocław 1985 - „Zeitschrift für Ostmitteleuropa-Forschung” 40 (1991), z. 1, s. 141-143; J. Jedlicki, Jakiej cywilizacji Polacy potrzebują. Studia $z$ dziejów idei i wyobrażeń XIX wieku, Warszawa 1988 - „Zeitschrift für Ostmitteleuropa-Forschung" 41 (1992), z. 3, s. 440-442; S. Kieniewicz, Dereszewicze 1863, Wrocław 1986 - „Zeitschrift für Ostmitteleuropa-Forschung” 40 (1991), z. 2, s. 297-298; C. Madajczyk, Dramat Katyński, Warszawa 1989 - „Zeitschrift für Ostmitteleuropa-Forschung” 41 (1992), z. 3, s. 449-450; C. W. Smith i jego polscy korespondenci 1861-1870, polska korespondencja z tłumaczeniami na duński ze wstępem i przypisami wydali P. Flandrup, K. Heltbergm, Kopenhaga 1997 - „Zeitschrift für Ostmitteleuropa-Forschung” 48 (1999), s. 308-308.

27 Powstanie styczniowe 1863-1864. Wrzenie, bój, Europa, wizje, red. S. Kalembka, Warszawa 1990 - „Zeitschrift für Ostforschung” 42, (1993), z. 2, 297-299; F. Ramotowska, Narodziny tajemnego państwa polskiego 1859-1862, Warszawa 1990 - „Zeitschrift für Ostforschung” 43 (1994), z. 2, s. $288-290$.

28 Memoriat ... do Napoleona z 1807 r., wyd. E. Halicz, „Przegląd Historyczny” 84 (1993), z. 1, s. 65-67; [rec.] S. Nicieja, Łyczaków - dzielnica za Styksem, Wrocław 1998 - „Przegląd Historyczny” 90 (1999), z. 4, s. 578-579; [rec.] M. Waldenberg, Narody zależne i mniejszości narodowe w Europie Środkowo-Wschodniej. Dzieje konfliktów i idei, Warszawa 2000 - „Przegląd Historyczny" 92 (2001), z. 1, s. 130-131. 


\section{Emanuel Halicz - not only his scientific profile}

\section{Abstract}

Emanuel Halicz (1921-2015) was a historian of the $19^{\text {th }}$ century. In 1939 he began his studies at the Ukrainian university in Lviv. In June of 1941 he was evacuated to the Mari Autonomous Soviet Socialist Republic. From 1943 a political officer in the Polish people's Army. A member of the Polish Workers' Party/ Polish United Workers' Party. In 1950 he earned a Ph.D. degree at the Jagiellonian University, Cracow, and was delegated from the army to the Institute for Training Scientific Cadres, where he was employed in 1952. From 1957 he was a lecturer at Feliks Dzerzhinsky Military Political Academy. In 1960 he became associate professor. A member of the committee of the Polish and Soviet Academies of Sciences created to edit and publish historical sources to the period of the January 1863 Uprising. He lost his job in the aftermath of March '68. In 1971 he emigrated to Denmark, and was demoted to the rank of private. In 1972-1982 he was professor at Odense University, in 1982-1990 at the University of Copenhagen. He collaborated with the Polish émigré periodical Zeszyty Historyczne.

Translated by Grażyna Waluga

\section{Эмануэль Галич - не только научный портрет}

\section{Аннотация}

Эмануэль Галич (1921-2015) был историком, специализирующемся на XIX веке. С 1939 учился на украинском университете во Львове. В июне 1941 был эвакуирован в Марийскую АССР. С 1943 - политический офицер Войска Польского. Член ППР/ПОРП. Получил докторскую степень на Ягеллонском университете в 1950. В 1950 направлен из армии в Институт образования научных кадров, с 1952 работник института. С 1957 преподаватель Военной политической академии им. Феликса Дзержинского. С 1960 экстраординарный профессор. Член комиссии польской и советской АН, созданной для издания источников по периоду Январского восстания. В результате марта 1968 был уволен с работы. В 1971 эмигрировал в Данию. Был разжалован с полковника до рядового. В 1972-1982 гг. - профессор университета в Оденсе, 1982-1990 - Копенгагенского университета. Сотрудник эмиграционных „Исторических тетрадей”.

Перевод Агнешка Поспишиль

\section{Bibliografia}

\section{Archiwalia:}

Archiwum Akt Nowych - Akademia Nauk Społecznych, wyk 42/56.

Centralne Archiwum Wojskowe.

Instytut Pamięci Narodowej, Ka 0024/28, t.1-5. 


\section{Opracowania:}

Bińko B., Instytut Kształcenia Kadr Naukowych przy KC PZPR - narzędzie ofensywy ideologicznej w nauce i szkolnictwie wyższym, „Kultura i Społeczeństwo” 40 (1996), nr 2, s. 199-214.

Bińko B., Skąd przychodzili, dokąd zmierzali... aspiranci pierwszego rocznika Instytutu Kształcenia Kadr Naukowych przy KC PZPR, w: Komunizm. Ideologia, system, ludzie, red. T. Szarota, Warszawa 2001, s. 192-204.

Ciupiński A., Wojskowa Akademia Polityczna im. F. Dzierżyńskiego 1951-1986, Warszawa 1986. Horoszko E., Kaczmarska P., Wojskowa Akademia Polityczna im. Feliksa Dzierżyńskiego 19511990 w świetle akt Archiwum Ministerstwa Obrony Narodowej, „Rocznik Archiwalno-Historyczny Centralnego Archiwum Wojskowego" (2011), nr 4, s. 167-206.

Kowalski L., Generał ze skazą. Biografia wojskowa gen. armii Wojciecha Jaruzelskiego, Warszawa 2001.

Kozerawski D.S., Wyższe szkolnictwo wojskowe w Polsce w latach 1947-1967, Warszawa 2005.

Kto jest kim w Polsce, red. B. Cynkier, wyd. 4, Warszawa 2001.

Nowak T.M., $Z$ dziejów organizacji badań nad historiq wojskowa w Polsce Ludowej, „Studia i Materiały do Historii Wojskowości” 30 (1988), s. 19-42.

Rutkowski T., Nauki historyczne w Polsce 1944-1970. Zagadnienia polityczne i organizacyjne, Warszawa 2007.

Szumski J., Polityka a historia. ZSRR wobec nauki historycznej w Polsce w latach 1945-1964, Warszawa 2016.

Wykaz członków Komitetu Redakcyjnego i Redakcji „Studiów i Materiałów do Historii Wojskowości” w latach 1954-1987, „Studia i Materiały do Historii Wojskowości” 30 (1988), s. 40.

„Zeszyty Naukowe WAP im. F. Dzierżyńskiego” (1981), nr 107 (O historii i historykach w Wojskowej Akademii Politycznej).

Michał Kozłowski (Lublin) - historyk bez afiliacji, mediewista. Zajmuje się historią Bizancjum oraz historią historiografii. Publikował m.in. w „Histmag”, „Kulturze Liberalnej”, „Meandrze”, „Mówią Wieki”, „Nowym Filomacie”, „Roczniku Instytutu Europy Środkowo-Wschodniej”, „Studiach i Materiałach Instytutu Europy Środkowo-Wschodniej”, „Tece Historyka”, „Vox Patrum”. Zajmował się twórczością różnych historyków, min.: Ihora Ševčenki (przypisy i bibliografia do książki Zakorzeniony kosmopolita. Ihor Szewczenko $w$ rozmowie $z$ Łukaszem Jasina, Lublin 2010), Oskara Haleckiego i jego uczniów (Oskar Halecki i jego wizja Europy, t. 1-3, 2012-2014), Stanisława Kościałkowskiego i jego uczniów, Henryka Paszkiewicza, Aleksandra Turyna, Kazimierza Zakrzewskiego (michalbyz@wp.pl).

Michał Kozłowski (Lublin), historian medievalist; his main scope of interest is the history of Byzantium and history of historiography. The author of numerous publications in: Histmag, Kultura Liberalna, Meander, Mówia Wieki, Nowy Filomata, Rocznik Instytutu Europy Środkowo-Wschodniej, Studia i Materialy Instytutu Europy Środkowo-Wschodniej, Teka Historyka, Vox Patrum. He also researched into the works of various historians, such as: Ihor Ševčenko (notes and literature to the book Zakorzeniony kosmopolita. Ihor Szewczenko w rozmowie z Łukaszem Jasina, Lublin, 2010), Oskar Halecki and his students (Oskar Halecki i jego wizja Europy, vols. 1-3, 2012-2014), Stanisław Kościałkowski and his students, Henryk Paszkiewicz, Aleksander Turyn, Kazimierz Zakrzewski (michalbyz@wp.pl). 